УДК 94(438:477)”1989/1999”: 327

Tetiana Yelova,

Post-Graduate Student, Political Science and National

Security Department

Lesya Ukrainka Volyn National University,

ORCID ID: 0000-0002-1059-5795

tanya.yelova@gmail.com

DOI 10.29038/2524-2679-2020-02-127-136

\title{
UKRAINE IN POLISH EASTERN POLICY OF 1990s: THE WAY TO PARTNERSHIP
}

With the collapse of the Soviet system and the start of systemic transformations in Central and Eastern Europe, which began at the turn of the 1980s and 1990s, there was an urgent need to review the existing system of international relations and find new formats for interstate and interethnic relations development. Polish-Ukrainian relations were no exception in this process. In the period of 1989-1999, Ukraine occupied a very important place in the foreign policy of the Republic of Poland, holding a leading position in Polish Eastern policy. It is at this time that the bilateral relations of young independent states were being formed and developed, which took an evolutionary step by establishing and supporting good neighborly relations to the level of strategic partnership. Eastern policy was the key to the positive dynamics of the development of Polish-Ukrainian relations; it has been tested and successfully implemented by the Polish governments of Solidarity since the early 1990s.

The main goal of Polish Eastern policy was to respond to the changes taking place on the eastern border of the Republic of Poland and to establish relations with the former republics of the Soviet Union, especially those that shared a border with Poland. This was predetermined by the desire to preserve the territorial integrity of the Republic of Poland and by the considerations of national security. The very formation and evolution of Polish-Ukrainian relations in the period of 1989-1999, known in history as the period of Poland's implementation of Eastern policy, are analyzed in this article.

Key words: Eastern policy, partnership, Republic of Poland, Ukraine, interstate relations, foreign policy, strategic partnership, cooperation.

(C) Yelova T., 2020 


\section{INTRODUCTION}

Formulation of the research problem. The process of shaping Polish foreign policy since 1989 has been quite complex and controversial, as the Polish political elite faced a difficult task. i.e., to develop a clear position on the changes that were taking place rapidly in Western and Eastern Europe. The collapse of the Soviet Union and the increasingly clear declarations of independence of its republics, including Ukraine, affected the need for Polish diplomacy to accept new geopolitical realities with special sobriety and caution and to join the international political life of the region. These circumstances made the political elite of the Republic of Poland approach the formation of foreign policy carefully and cautiously.

Eastern policy, which was also called the policy of two vectors (or two ways), became the main concept of the foreign policy of the Republic of Poland in the eastern direction. The main goal of Polish Eastern policy was to respond to the changes taking place on the eastern border of the Republic of Poland and to establish relations with the former republics of the Soviet Union, especially those that shared a border with Poland. This was predetermined by the desire to preserve the territorial integrity of the Republic of Poland and by the considerations of national security. Ukraine, as the closest eastern neighbor of the Republic of Poland, as well as the country with which Poland has the longest border, took a central position in the Eastern policy.

Analysis of recent research and publications. The present article is based on materials published by domestic and Polish authors, that is political scientists, historians and politicians. In particular, the works by K. Skubiszewski [1], who headed the Ministry of Foreign Affairs of the Republic of Poland in the early $1990 \mathrm{~s}$, are extremely valuable for the researcher and they complement the scientific studies of such Polish scientists as J. Nowakowski [2] and K. Fedorowicz [3]. For instance, the Poznan political scientist K. Fedorowicz published a thorough monograph «Ukraine in Polish Eastern Policy, 19891999» in which he comprehensively studied the Polish policy of two vectors and analyzed the place of Ukraine in it. The mentioned work is based on a wide range of sources and is extremely informative and full of interesting facts. This monograph is widely cited in this paper.

The article by M. Zanevych, a Polish historian and publicist, is interesting, and one of the newest in the mentioned thematic field. The author analyzes the genesis of Poland's foreign policy doctrines regarding its eastern neighbors and Ukraine in particular. A significant place in the cited work is given to the eastern policy of the Republic of Poland. 
The scientific achievements of Ukrainian authors are also large and diverse. Thus, for the presented research, the works by L. Strilchuk [4;6], a Volyn researcher, were of utmost importance as she published a number of articles and monographs that are relevant to the subject of this research. A joint monograph by L. Strilchuk and Yu. Pasichnyk [5] should not be overlooked; one of its sections is devoted to the analysis of Poland's Eastern policy regarding Ukraine in the period under study.

Aim of the article. The article is aimed to find out the reasons for the emergence of Eastern policies and to analyze its evolution during the 1990s. The author also sets the task to trace the peculiarities of the implementation of the two-way policy and the vision of the role of Ukraine by the Polish political elite in this policy.

Research methodology. The research methods used in the article correspond with the methodology of political science. In general, there is a progression towards methodological pluralism, which involves expanding the range of rationality, rather than being limited only by analytical methods; idea of methodology as a way to combine and unify methods and their interpretation; determining the possibility of different methods and their use to optimize the results of cognition. The methodology of the conducted scientific research has several levels, in particular: general scientific, philosophical, technological and specific-scientific. Thus, general scientific methodology is a theoretical concept that is widely used in the proposed article.

\section{RESEARCH RESULTS}

Presentation of the main material and substantiation of the research results. At the turn of the 1980s and 1990s, Polish and Ukrainian societies, with a difference of several years, won independence and tried to build their own state on the fundamental democratic principles of civilization. The rapid formation of a strong mechanism of power structures, in particular the institution of the Presidency, which undertook the implementation of foreign policy doctrines was an important achievement of the Polish establishment. Instead, the Ukrainian democratically-minded elite, which would reflect the national idea and interests of all segments of the population, did not stand out from the general mass, and therefore, in the early 1990s, Ukraine differed significantly from the neighboring Republic of Poland not only in the level of government institutions formation, but also in the development and implementation of foreign policy concepts. 
The victory of Solidarity in the Republic of Poland in the elections of June 4, 1989, was not only the beginning of a new period in the country's history, but it also brought to the fore of the Polish political elite the question of Eastern policy forms. In fact, the new Eastern policy, also called the policy of two vectors, showed that the painstaking work of Polish emigrants J. Giedroyc and J. Mieroszewski, the publishers of the magazine «Culture», was not in vain, because their postulates of Polish Eastern policy, developed in previous decades, could be implemented in new geopolitical realities.

In fact, since 1989 the process of shaping Polish foreign policy has been quite complex and controversial, because from the very beginning it was necessary to develop a clear position on the changes that took place in the West, and more importantly - in the East. The crisis, and later the collapse of the Soviet Union, posed an important task for the Polish political elite, namely, to approach the formation of a new foreign policy of the Third Rzeczpospolita with special balance.

That is why the most important goal of the new Polish Eastern policy was to respond to the changes developing abroad [4, p. 516]. K. Fedorowicz, a Poznan political scientist, believes that, first of all, this was predetermined by considerations of state security, attempts to prevent a situation in which the Polish eastern border could become a zone of tension [3, p. 226]. The two-vector policy, pursued by the Polish political elite in 1990, was aimed, on the one hand, to support the former Soviet republics seeking independence and, on the other, to maintain contact with the Soviet authorities and not to violate the Warsaw Pact. In fact, it was a kind of a balancing act with looking back at Moscow.

According to the Polish researcher J. Nowakowski, the foreign policy of the Republic of Poland in the eastern direction at the turn of the 1980-1990s concentrated on three main principles, namely:

- to preserve Soviet structures and to support the reforms initiated by Mikhail Gorbachev;

- to support some republics of the USSR, especially Ukraine, as its closest eastern neighbor (so-called modern Prometheanism);

- to maintain close relations with Russia, as the successor to the USSR [2, p. 87].

One should mention that all these concepts were developed in parallel, none of them was a priority, but at the same time Polish diplomacy perceived Ukraine in a special way (given its importance in the region and importance for Poland as well) in shaping Eastern policy in the period of 1989-1999. The evolution of the Eastern policy of the Republic of Poland is inextricably 
linked with the democratic processes in Poland itself and with the formation of the first government of Solidarity by T. Mazowiecki, as well as with the loss of relevance of Polish-Soviet relations [5, p. 56]. This was a rather complicated process, which did not involve rapid changes in relations with Poland's eastern neighbors [6, p. 142]. As K. Skubiszewski, the Minister of Foreign Affairs of the Republic of Poland in the early 1990s, emphasized, the essence of the policy of two vectors (or policy of «two ways») was to: $«$... maintain the necessary relations with the so-called center, i.e. Moscow, and equal relations with the USSR republics, primarily with Ukraine, Belarus and Russia, bypassing the center... » [1, p. 271]. In fact, on this very basis President Lech Wałęsa implemented Poland's foreign policy.

L. Strilchuk, a Ukrainian researcher of Ukrainian-Polish relations, claims: «the shift of emphasis in the Polish policy towards Ukraine dates back to the beginning of 1994 and is connected with the victory of the left coalition in the parliamentary elections and the formation of W. Pawlak's government. At that time, the Polish Foreign Ministry was headed by A. Olechowski, known for his sympathies for Ukraine, and criticism of Western countries for their sympathy for Russia. The head of the Polish Ministry of Foreign Affairs stated that the Republic of Poland sought to open a new chapter in its Eastern policy and identified three main tasks in this regard: to build multilateral relations with Russia, Ukraine, Belarus, Moldova, Kazakhstan and the Baltic states; to promote political and military stabilization in the region; to create conditions for economic cooperation of Poland with its neighbors in the East [6, p. 146-147].

In fact, Olechowski 's initiative to adjust Poland's Eastern policy was aimed at strengthening Poland's trade and other relations with its eastern neighbors, and included a program to assist these countries in building democratic institutions and market economies. The author of the article fully agrees with the opinion of S. Burant, the authoritative researcher of modern Polish-Ukrainian relations, that such a position was nothing but Poland's attempt to play the same role in relation to its eastern neighbors, which Western countries previously had tested on the Republic of Poland [7, p. 101].

The implementation of the Eastern policy and the common desire of Ukraine and Poland to develop and deepen bilateral relations in all areas (political, economic, humanitarian) as well as the consistent pursuit of the chosen course of cooperation led to a qualitatively new stage in relations between neighboring countries. The term «strategic partnership» has been used to describe Polish-Ukrainian relations since the mid-1990s. This term was first used in the Communiqué following the meeting of the Advisory Committee of the Presidents of Ukraine and the Republic of Poland, which 
took place on September 27-28, 1995. It, in particular, stated: «The parties agreed that it was necessary to find adequate organizational forms in order to ensure the practical effectiveness of their strategic partnership» [8, p. 39-41]. Thus, Polish-Ukrainian interstate relations, their expansion and harmonization, as well as the strategic partnership as their qualitatively new dimension served as a bridge for Ukraine on the world international arena, and the Republic of Poland became the guide for this state on the way to Europe and the world.

Since the end of 1995, bilateral Polish-Ukrainian contacts have intensified, so Ukraine again occupied a central place in Polish Eastern policy, and the period of 1996-1997 was called the «renaissance» of Ukraine in Polish foreign policy [3, p. 229]. This was due to numerous factors, both internal and external.

1997 was a year of extremely important joint strategic decisions made by neighboring Ukraine and Poland. Cooperation between Ukraine and the NATO, as well as Ukraine and the EU was institutionalized. It was in 1997, together with the Republic of Poland, that this state took a number of steps to strengthen regional and European security. The presidents of the neighboring countries came to the common conclusion that there was a direct relation between the degree of bilateral interstate relations and the level of collective security. In May 1997, Presidents

L. Kuchma and A. Kwaśniewski, along with the Presidents of the three Baltic States, took part in the Tallinn Meeting on Regional Security. In fact, this event showed that one of the consequences of the strategic Ukrainian-Polish partnership was the strengthening of multilateral dialogue on joint regional initiatives in the field of security [6, p. 150].

The signing of the Joint Declaration «Towards Understanding and Unity» by the leaders of both countries which took place in Kyiv in May 1997 was one of the highlights of the implementation of Eastern policy. Along with the great importance of the Joint Declaration, this document played an invaluable role in the cause of interethnic reconciliation, smoothing out the sharp stones of misunderstanding in the field of the historical memory of neighboring peoples.

The 1990s became an important stage in the development of PolishUkrainian bilateral relations. The bilateral cooperation resulted in the change in Western policy towards Ukraine. During the 1990s, the Republic of Poland constantly and consistently acted as a mediator between Ukraine and the countries of Western Europe, lobbying Ukrainian interests. L. Strilchuk claims in this regard the following: "The example of Polish-Ukrainian relations has shown for Europe and the world that Ukraine can be a full and equal participant in international politics, and it is necessary to establish and develop close contacts, which are clearly beneficial for all parties» [4, p. 518]. 
One should acknowledge that the 1990s vividly demonstrated the consistency of Polish Eastern policy until the beginning of the 21 st century. This was manifested in numerous examples, for instance, Poland became one of the first countries in the world to recognize Ukraine's independence on December 2, 1991; since 1997, the Republic of Poland and Ukraine have already announced a strategic partnership in bilateral relations; Eastern policy can be clearly seen in Poland's support for Ukraine during the Orange Revolution, and later the states jointly held the 2012 Euro football championship. These are just some examples of positive progress in the development of Polish-Ukrainian relations.

After the Civic Platform came to power in the Republic of Poland, a new Polish concept of Eastern policy emerged, namely, the concept of detente in relations with Russia, modeled on the policy of the German Foreign Minister F.-W. Steinmeier [9]. The then head of the Polish Ministry of Foreign Affairs R. Sikorski, was the author of its Polish version whose doctrine created a paradoxical situation when the Polish government implemented the concept of detente, while President L. Kaczynski continued to pursue a policy of Prometheanism in the east [5, p. 56-57].

In fact, the struggle between the two foreign policy concepts of Eastern policy came to an end due to the tragic death of President L. Kaczynski in April 2010. However, already in 2013, R. Sikorski delivered a speech in which he emphasized the priority of relations with Germany and Brussels in order to strengthen the position of the Republic of Poland in the European arena [9]. This position marked a departure from Eastern policy.

\section{CONCLUSIONS AND PROSPECTS OF FURTHER RESEARCH}

Post-Soviet Eastern Europe and post-socialist Central and Eastern Europe have become new elements of political geography, their unique role is to construct and configure the national interests of European security. The task of Polish Eastern policy was a one-vector pro-Western direction in the development of foreign policies of post-Soviet countries and the prevention of possible geo-military and geostrategic dichotomy in Eastern Europe. That is, we speak about the implementation of the policy of preventing the bloc division of the post-Soviet and post-socialist space, as well as the emergence of post-Soviet totalitarianism.

As a result, we can argue that in the period of 1989-1999 Ukraine entered the Polish Eastern policy quite strongly and occupied one of the most privileged positions in it $[3$, p. 230]. As a result of the implementation of the 
Eastern Policy of the Republic of Poland, the two neighboring states Ukraine and Poland not only established bilateral relations and cooperation, but also developed them to the level of strategic partnership. The path to strategic partnership was paved by both countries with maximum effort and goodwill. During this period, the Republic of Poland was an active lobbyist for Ukrainian interests in the international arena. Thus, Poland's Eastern policy towards Ukraine in the 1990s was successful and fully met all expectations.

\section{REFERENCE}

1. Skubiszewski, K. (1997). Polityka zagraniczna i odzyskanie nepodleglosti. Przemówienia, oświadczenia, wywiady 1989-1993, Warszawa, $434 \mathrm{~s}$.

2. Nowakowski, J. (1991). Polska polityka wschodnia w 1991 roku. Rocznik Polskiej Polityki Zagranicznej, 77-88.

3. Fedorowicz, K. (2004). Ukraina w polskiej polityce wschodniej w latach 1989-1999, Poznań, 249 s.

4. Стрільчук, Л. (2008). Україна в польській східній політиці 1989-1999рp. III Міжнародний науковий конгрес українських істориків. «Українська історична наука на шляху творчого поступу». Луцьк, 17-19 травня 2006 р.: доп. та повідомл.: в 3-х т., Луцьк: РВВ «Вежа» Волин. наи. уні-ту ім. Лесі Украӥнки, 3, 515-519.

5. Стрільчук, Л., Пасічник, Ю. (2020). Президентський вимір сучасних польськоукраӥнських відносин: монографія. Луцьк,Терези, 360 с.

6. Стрільчук, Л. (2013). Україна - Польща: від добросусідських відносин до стратегічного партнерства (кінець XX - XXI століття): монографія. Луцьк, Волинські старожитності, $608 \mathrm{c}$.

7. Бурант, С. (1997). Україна і Польща: до стратегічного партнерства. Політична думка, 3, 99-111.

8. Czech, M. (1997). Głos w dyskusji. Próby oceny polskiej polityki wschodniej w latach 1988-1990. Rocznik Wschodni, 4, 39-41.

9. Заневич, М. (2017). У полоні старих концепцій: що впливає на українську політику Польщі, URL: https://www.eurointegration.com.ua/articles/2017/10/19/7072409 (дата перегляду: 12.03.2020).

\section{УКРАЇНА В ПОЛЬСЬКІЙ СХІДНІЙ ПОЛІТИЦІ 90-х РОКІВ ХХ СТОЛІТТЯ: ШЛЯХ ДО ПАРТНЕРСТВА}

Із розвалом радянської системи та початком системних трансформацій у країнах Центрально-Східної Свропи, що розпочалися на рубежі 80-90-х років XX ст., постала нагальна потреба перегляду системи міжнародних відносин та пошуку нових форматів побудови міждержавних та міжнаціональних взаємин. Не стали винятком у цьому процесі й польсько-українські відносини. 
У 1989-1999 рр. Україна посідає досить важливе місце в зовнішній політиці Республіки Польща, відіграючи провідну роль у польській східній політиці. Саме в цей час відбуваються становлення та розбудова двосторонніх відносин молодих незалежних держав, які зробили еволюційний крок, налагодовши та розвинувши добросусідські відносини до рівня стратегічного партнерства. Запорукою позитивної динаміки розвитку польсько-українських відносин стала східна політика, що від початку 90-х років XX ст. була апробована й успішно втілювана в життя польськими урядами солідарності.

Головною метою польської східної політики стало реагування на зміни, що відбувалися за східним кордоном Республіки Польща та налагодження відносин із колишніми республіками Радянького Союзу, передусім із тими, що мали спільний кордон із Польщею. Це продиктовано прагненням зберегти територіальну інтегральність Республіки Польща та міркуваннями національної безпеки країни. Саме становлення й еволюцію польськоукраїнських відносин періоду 1989-1999 рр., відомих в історії, як період здійснення Польщею східної політики, аналізуємо в цій статті.

Ключові слова: східна політика, партнерство, Республіка Польща, Україна, міждержавні відносини, зовнішня політика, стратегічне партнерство, співробітнцтво.

\section{REFERENCES}

1. Skubiszewski, K. (1997). Polityka zagraniczna i odzyskanie nepodleglosti. Przemówienia, oświadczenia, wywiady 1989-1993, Warszawa, 434.

2. Nowakowski, J. (1991). Polska polityka wschodnia w 1991 roku. Rocznik Polskiej Polityki Zagranicznej, 77-88.

3. Fedorowicz, K. (2004). Ukraina w polskiej polityce wschodniej w latach 19891999, Poznań, 249 p.

4. Strilchuk, L. (2008). Ukraina v polskii skhidnii politytsi 1989-1999 rr. III Mizhnarodnyi naukovyi konhres ukrainskykh istorykiv. «Ukrainska istorychna nauka na shliakhu tvorchoho postupu». Lutsk, 17-19 travnia 2006 r.: Dopovidi ta povidomlennia: V 3-kh tomakh, Lutsk: RVV «Vezha» Volyn. nats. un-tu im. Lesi Ukrainky, t. 3, 515-519.

5. Strilchuk, L., Pasichnyk, Yu. (2020). Prezydentskyi vymir suchasnykh polskoukrainskykh vidnosyn: monohrafiia, Lutsk, Terezy, $360 \mathrm{p}$.

6. Strilchuk, L. (2013). Ukraina - Polshcha: vid dobrosusidskykh vidnosyn do stratehichnoho partnerstva (kinets KhKh - KhKhI stolittia): monohrafiia, Lutsk: Volynski starozhytnosti, $608 \mathrm{p}$.

7. Burant, S. (1997). Ukraina i Polshcha: do stratehichnoho partnerstva. Politychna dumka, 3, 99-111.

8. Czech, M. (1997). Głos w dyskusji. Próby oceny polskiej polityki wschodniej w latach 1988-1990. Rocznik Wschodni, 4, 39-41. 
9. Zanevych, M. (2017). U poloni starykh kontseptsii: shcho vplyvaie na ukrainsku polityku Polshchi, rezhym dotupu: https://www.eurointegration.com.ua/articles/2017/10/19/7072409 (data perehliadu: 12.03.2020).

Матеріал надійшов до редакиї 18.11.2020 p.

УДК 327.82(1-622НАТО):623.454.8-047.64

\section{Тетяна Мельник,}

науковий співробітник,

Одеського центру з питань нерозповсюдження

Одеський національний університет імені I. I. Мечникова,

ORCID ID: 0000-0001-6744-2610

Tetianamelnique@gmail.com

DOI 10.29038/2524-2679-2020-02-136-155

\section{РЕЖИМ НЕРОЗПОВСЮДЖЕННЯ ЯДЕРНОЇ ЗБРОЇ ТА КОНТРОЛЮ НАД ОЗБРОЕННЯМИ, ЯК НАДСИСТЕМА Й ГАРАНТ СТАБІЛЬНОСТІ СВРОАТЛАНТИЧНОЇ СИСТЕМИ}

У статті розглянуто режим нерозповсюдження ядерної зброї та контролю над озброєннями як комплексне середовище Свроатлантичної безпекової системи, ї̈ надсистему й міжнародне поле взаємодії з іниими акторами. Розглянуто фундаментальну роль Договору про нерозповсюдження ядерної зброї (ДНЯЗ) як системоутворювального договору та вплив сучасної міжнародної динаміки на розгойдування основ контролю над озброєнням. Особливу увагу приділено причинно-наслідковим зв'язкам у процеесах, щуо відбуваються у двох системах, і яке відображення вони знаходять одна в іншій.

Говорячи про систему нерозповсюдження, підкреслюємо роль НАТО й США. Розглядаються пов'язані з ичм контроверсійні питання. Проаналізовано внесок Заходу в досягнення без'ядерного світу та стримувальні фактори на цүьому етапі. Окремо відзначено, щзо наразі ядерна гонка озброєнь проявлясться не в кількісному, а в якісному вимірі в контексті масштабних модернізаційних проєктів ядерних держав.

Водночас виокремлено деструктивний вплив виходу США з низки міжнародних договорів, як-от Договір про ракети середньої й меншой

(C) Мельник T., 2020 